DOI: 10.34015/2523-4552.2019.2.06

УДК 343.2

Денисов С. Ф., доктор юридичних наук, професор

Шишова А. Я., здобувач Академії Державної пенітенціарної служби України

\title{
ХАРАКТЕРИСТИКА КРИМІНАЛЬНОГО КОДЕКСУ РУМУНІЇ
}

Стаття присвячена дослідженню Кримінального кодексу Румунії. Належне нормативне регулювання інституту кримінальної відповідальності та наявність узгодженої концепції його розуміння $\epsilon$, безумовно, важливими для кримінально-правової політики держави. У статті розглянуто основні та додаткові види покарань, що передбачені за вчинення злочинів у цій державі, принципи, за якими діє Кримінальний кодекс Румунії. Окреслено також систему Особливої частини Кримінального кодексу Румунії. Коротко охарактеризовано правову систему Румунії.

Ключові слова: правова система Румунії; Кримінальний кодекс Румунії; Загальна частина Кримінального кодексу Румунії; система Особливої частини Кримінального кодексу Румунії.

Статья посвящена исследованию Уголовного кодекса Румынии. Должное нормативное регулирование института уголовной ответственности и наличие согласованной концепции его понимания является, безусловно, важным для уголовно-правовой политики государства. В этой статье рассмотрены основные и дополнительные виды наказаний, предусмотренные за совершение преступлений в этом государстве, принципы, по которым действует Уголовный кодекс Румынии. Очерчено также систему Особой части Уголовного кодекса Румынии. Коротко охарактеризовано правовую систему Румынии.

Ключевые слова: правовая система Румынии; Уголовный кодекс Румынии; Общая часть Уголовного кодекса Румынии; система Особенной части Уголовного кодекса Румынии.

Постановка проблеми. Сучасна правова система Румунії серед інших постсоціалістичних країн $\epsilon$ досить розвиненою, хоча шлях до створення сучасної держави був важким через вплив різних політичних режимів. Саме через неоднорідність цих режимів правова система була недосконалою. Відомий французький правник М. Ансель досить слуш- но зазначає, що вивчення зарубіжного права відкриває перед юристом нові горизонти, які дозволяють краще пізнати право своєї держави, адже специфічні його риси особливо яскраво виявляються лише при порівнянні з іншими системами. Правова система цієї держави є маловідомою для нас, що спонукає у майбутньому до глибоких досліджень. 3 розвит- 
ком суспільства все змінюється, що потребує змін у державній політиці, зокрема й у кримінальному праві.

Необхідно зазначити, що Кримінальний кодекс (далі - КК) Румунї̈ мало досліджений українськими науковцями. Не виключено, що з часом нашій державі можна буде запозичити досвід цієї країни і додати до КК України певні новації, які б могли сприяти розвитку сфери правозастосування. Зокрема, сьогодні держави встановлюють більш гуманні покарання для засуджених.

Як відомо, Румунія входить до романо-германської правової сім'ї. Румунське право з моменту створення незалежної держави на початку XIX ст. тяжіло до романської правової культури. Водночас географічне положення Румунії визначило її історичний зв'язок з візантійською правовою спадщиною. Протягом століть на значній частині території сучасної Румунії діяло візантійське право, що являло собою переробку класичного римського права у феодальному i частково релігійному дусі. У XVIII ст. у Валахії почався процес відродження візантійського права, але вже на початку XIX ст. він був перерваний рецепцією спочатку австрійського, а потім і французького права [1].

Більшість основних галузей права були кодифіковані у другій половині XIX ст. Необхідно вказати, що деякі кодекси цього періоду частково діють і зараз. У 1950-1980 pр. румунська правова система, зберігаючи міцний зв'язок 3 романогерманським правом, входила в соціалістичну правову сім'ю [2]. У 1990-ті роки правова система Румунії була значною мірою оновлена згідно 3 принципами і нормами демократичної Конституції 1991 р. Однак, не- зважаючи на формальне повернення Румунії в романо-германську правову сім'ю, сучасний менталітет румунів далекий від західноєвропейського. Їх поведінка досить часто визначається не приписами нових демократичних законів, а стереотипами, що успадковані від недавнього тоталітарного минулого [3].

Аналіз останніх досліджень і публікацій. Теоретичною базою написання статті стали наукові праці вітчизняних та зарубіжних вчених, зокрема таких, як M.І.Бажанов, П. С. Берзін, .М.Брайнін, О. О. Дудоров, В. В. Кузнецов, С. Я. Лихова, В. О. Навроцький, А. В. Савченко, П. П. Сердюк, Є. Л. Стрельцов, В. О. Туляков, П. Л. Фріс, М. І. Хавронюк, С. С. Яценко та інших дослідників. Незважаючи на їх суттєвий внесок, можна констатувати, що питання кримінального права Румунії українські вчені розглядали лише фрагментарно.

Постановка завдання. Метою статті є ознайомлення з КК Румунії та вивчення його основних положень для можливого вдосконалення КК України.

Виклад основного матеріалу. Основним законом Румунії є Конституція, прийнята в грудні 1991 р. і переглянута в жовтні 2003 р. Румунську судову систему реформовано на початку 2010-х років з уведенням чотирьох нових кодексів: Цивільного (2011 р.), Цивільно-процесуального (2013 р.) [4], Кримінального та Кримінально-процесуального (2014р.).

Основним джерелом кримінального права Румунії $є$ Кримінальний кодекс Румунії $[5,6]$, який набрав чинності 1 лютого 2014 р. КК систематизований законодавчий акт, який урегульовує питання виключ- 
ного переліку діянь, що є кримінальними правопорушеннями, також він установлює підстави кримінальної відповідальності та передбачає види покарань та (або) заходи безпеки до осіб, що вчинили заборонену дію [7], або ж не вчинили нічого, що могли, для відвернення злочину (наприклад, залишення особи в небезпеці). Водночас предметом регулювання КК $€$ також інші, крім зазначених пунктів, а саме: питання матеріального кримінального права, що пов'язані зі злочинами (проступками) і відповідальністю за їх учинення.

Загальновизнано, що КК може бути єдиним джерелом кримінального права певної країни - у разі, коли кримінальне право повністю кодифіковане (Україна і країни СНД). Коли ж система джерел кримінального права не вичерпується лише кримінальним кодексом, а кримінально-правові норми викладено в окремих законах про кримінальну відповідальність (наприклад, стосовно неповнолітніх або юридичних осіб, покарання стосовно їх можуть бути прописані в законах про військові злочини або військових кримінальних кодексах, тощо), то ці закони діють одночасно з КК (такі закони існують, зокрема, у Чехії, ФРН та інших країнах).

Кримінальні кодекси сучасних держав прийняті в різні часи для того, щоб відповідати сучасним потребам боротьби зі злочинністю. Кримінальне законодавство досить часто оновлюється шляхом часткового реформування окремих інститутів (наприклад, Шостий закон про реформу кримінального права 1998 р. у ФРН) або повної рекодифікації (наприклад, у 2009 р. в Румунії прийнято новий КК, який мав би за- мінити КК Румунії 2004 р., але головною проблемою стало те, що КК Румунії 2004 р. ніколи так і не набирав чинності [7], тому КК Румунії 2009 р. фактично замінив КК Румунії 1969 p.).

КК Румунії став юридичною базою кримінальної політики румунської держави у XXI ст. Він створювався на основі попереднього КК, але до уваги бралися зміни в суспільстві, які вже відбулися і будуть відбуватися в майбутньому. Створюючи КК, румунський законодавець головним чином мав такі цілі: сформувати цілісну правову базу з кримінально-правової точки зору, уникаючи марного застосування чинних норм, що існують в чинному КК та спеціальних законах; полегшити швидке та уніфіковане застосування кримінального законодавства в діяльності судових органів; переведення правил, прийнятих на рівні Європейського Союзу, в національну кримінально-правову базу; гармонізувати румунське кримінальне право із системами інших держав, що діють у Європейському Союзі. Вирішуючи ці завдання, автори КК Румунії намагалися зберегти основу кримінального права без змін. Зміст Загальної частини КК Румунії 1969 р. спирався на таку структуру: $\epsilon$ дві класичні категорії кримінального права - «злочин» і «покарання». Одночасно новий КК Румунії зазначає нові цілі, а саме: «виправлення особи, яка вчинила злочин», «попередження скоєння злочину будь-якою особою». Саме для досягнення цих цілей створено механізм реалізації кримінального покарання, що закріплений в новому КК Румунії.

КК Румунії визначає своїми головними завданнями правове забезпечення охорони прав і свобод лю- 
дини і громадянина, власності особи, громадського порядку та громадської безпеки, довкілля, конституційного устрою Румунії від злочинних посягань, забезпечення миру і безпеки людства, а також запобігання злочинам. Статті Загальної частини КК Румунії містять норми, що встановлюють принципи і загальні положення кримінального права, чинність кримінального закону в просторі і часі, визначають поняття злочину, стадії вчинення умисного злочину, ознаки суб'єкта злочину, зміст вини, поняття співучасті, види множини злочинів, обставини, що виключають злочинність діяння, підстави звільнення від кримінальної відповідальності та від покарання і його відбування, загальні засади призначення покарання тощо.

КК Румунії 2014 р. складається з 446 статей. Загальна частина починається статтею 1 і закінчується статтею 187 , містить X розділів. Особлива частина складається з XIII розділів, починається зі статті 188 і закінчується статтею 466.

Загальну частину Кодексу відкриває розділ «Кримінальне право та межі його застосування». У ньому визначено завдання КК Румунії та межі його дії. Перші зміни, що відбулися в новому КК Румунії порівняно з попереднім, можна побачити відразу ж, адже змінилася назва розділу I (порівняно з попереднім кодексом «Кримінальне право та його застосування»). Загальна частина об'єднує норми, що визначають завдання, принципи, основні інститути кримінального права. Спираючись на КК Румунії, можна виділити такі принципи, за якими він діє:

1. Територіальнии. Згідно 3 цим принципом особа карається за злочин, що вчинений на території Румунії, або ж на судні під прапором Румунії, або ж на зареєстрованому в цій державі транспортному засобі.

2. Особисто1 кримінальної відповідальності. За цим принципом особа повинна нести покарання тільки за злочин, який учинила особисто.

3. Румунського кримінального права. Цеи принцип полягає в тому, що особа, яка вчинила за кордоном злочин, що загрожує румунськіи державі та іï громадянам, повинна бути засуджена за КК Румунії.

Також, на відміну від попереднього КК Румунії, де принципи розглянуто в одній статті, у новому законі принцип законності та кримінально-правових санкцій «розділено» на дві статті: застосування законності (стаття 1) і кримінально-правові санкції (стаття 2) [8, с. 3]. У диспозиції статті згадується, що законодавчий орган повинен звернути увагу на наслідки, які випливають з цих правил, зокрема, на заборону зворотного застосування кримінальної норми. Що стосується кримінального законодавства (стаття 6) $[8$, с. 5, 7], то новий КК Румунії також передбачає загальне визначення злочину, яке суттєво відрізняється від КК 1969 р. Відповідно до статті 15 КК Румунії «злочин - це діяння, яке передбачене кримінальним законом, учинене особою умисно або 3 необережності i містить у собі вину» $[8$, с. 10$]$.

Зміни в призначенні покарання зачепили як основні, так і додаткові види покарання. Відповідно до статті 53 КК Румунії [8, с. 25] основним покаранням $\epsilon:$ а) довічне ув'язнення (довічне позбавлення волі); б) ув'язнення (позбавлення волі); в) штраф.

Зміст додаткового покарання на заборону здійснення певних прав 
роз'яснює стаття 54 КК Румунії. У статті 55 КК Румунії зазначені додаткові покарання, а саме: а) позбавлення певних прав; б) позбавлення військового звання. Додаткове покарання у виді заборони здійснення прав полягає в обмеженні користуватися правами на період від одного до п'яти років:

а) право бути обраним у державних органах влади або на будьяку публічну посаду;

b) право займати посаду, пов'язану зі здійсненням державної влади;

c) право іноземця бути на території Румунії;

d) виборче право;

е) батьківські права;

f) право бути опікуном;

g) право займати посаду, або ж займатися професією, здійснювати діяльність, яка використовувалася для вчинення злочину;

h) право володіти та використовувати будь-яку категорію зброї;

i) право керувати певними категоріями транспортних засобів;

j) право виїзду з території Румунії;

k) право займати керівну посаду в юридичній установі, що регулюється публічним правом;

l) право бути в певних населених пунктах, установлених судом;

m) право бути в певних місцях, або на певних спортивних, культурних заходах, або на інших громадських зборах, обмежених судом;

n) право спілкуватися з потерпілим або членами його сім'ї, особами, з якими вчинила злочин, або 3 іншими особами, установленими судом, або навіть підійти до них;

о) право на підхід до будинку, робочого місця, школи чи до інших місць, де жертва здійснює соціальну діяльність на умовах, установлених судом.

Також змінився строк, на який застосовуються певні покарання, разом із цим змінено формулу, за якою перераховувався термін амністії [9, с. 123].

Законодавець переглянув обставини, які $\epsilon$ пом'якшувальними. Було вилучено пункт про поведінку матері, яка вчинила злочин. Наявність пом'якшувальних обставин дозволяє зменшення на 1/3 від максимального і мінімального покарання. У статті 75 КК Румунії [8, с. 50] зазначено пом'якшувальні обставини, а саме:

a) учинення злочину під впливом сильного душевного хвилювання, викликаного неправомірними діями потерпілого;

b) учинення злочину з перевищенням меж крайньої необхідносTi;

c) повне покриття матеріальних збитків.

Разом з указаним до пом'якшувальних обставин відносять:

а) зусилля правопорушника щодо усунення або пом'якшення наслідків злочину;

b) обставини, пов'язані з учиненим діянням, що зменшують тяжкість злочину або небезпеку.

У статті 77 КК Румунії вказано обтяжуючі обставини (ці обставини схожі $з$ тими, що $\epsilon$ в КК України), а саме:

a) учинення дій трьома чи більше особами;

b) учинення злочину жорстким шляхом або таким, що принижує гідність жертви;

c) учинення правопорушення методами або засобами, що можуть 
загрожувати іншим особам або речам / майну особи;

d) учинення правопорушення дорослою особою із залученням неповнолітньої особи;

е) злочин, що був учинений, користуючись станом жертви, особливо уразливої через свій вік, стан здоров'я, інвалідність або 3 інших причин;

f) учинення злочину в стані алкогольного сп'яніння або через уживання психоактивних речовин, які можуть спонукати до вчинення злочину;

g) учинення злочину особою, яка скористалася ситуацією, що склалася в умовах стихійного лиха, облоги або надзвичайного стану;

h) учинення злочину 3 расових, національних, етнічних, мовних причин, статі, сексуальної орієнтації, переконань або політичної приналежності, майнового, соціального походження, віку, інвалідності, заразних захворювань або ВІЛ/СНІДу.

У статті 99 КК Румунії визначено умови, за яких особа може звільнитися, якщо вона відбуває покарання у виді довічного позбавлення волі. Ув'язнений повинен дотриматися таких умов:

a) засуджена особа фактично відбула 20 років;

b) засуджений поводився добре протягом строку виконання покарання;

c) засуджений повністю дотримується цивільних обов'язків;

d) суд переконаний, що засудженому вдалося змінити свою поведінку. 3 моменту виходу засуджена особа підлягає 10-річному контролю.

Зміни, пов'язані із застосуванням до неповнолітніх видів кримінального покарання. Відповідно до по- ложень КК Румунії визначаються дві категорії правопорушників, до яких можна застосовувати виховні заходи: 1) позбавлені волі правопорушники; 2) не позбавлені волі правопорушники. Як правило, застосовуються виховні заходи без позбавлення волі, адже неповнолітні особи навчаються, тому покарання не повинно заважати отриманню освіти. Але якщо правопорушник учинив декілька злочинів, і вони тяжкі, до нього можуть застосувати виховні заходи 3 позбавленням волі [9, с. 124]. До переліку заходів належать такі:

1. Виховний захід. Правопорушник повинен максимум 4 місяці займатися громадськими роботами для усвідомлення наслідків своїх діянь.

2. Нагляд за неповнолітньою особою під час проходження виховних заходів.

3. Виховний захід у виді позбавлення волі неповнолітньої особи у вихідні дні.

4. Виховний захід у виді щоденної допомоги неповнолітньому. Правопорушник, який не може сам виправитися, може отримувати допомогу від служби пробації.

5. Тримання в СІ30.

Під Особливою частиною кримінального права Румунії як структурною частиною КК (або просто Особливою частиною КК) розуміється система кримінально-правових норм, що містять положення, які не $\epsilon$ загальними для всіх або більшості норм кримінального закону, у яких: а) зафіксовано видові ознаки окремих злочинів (ознаки юридичних складів злочину) та встановлено вид i розмір покарання за їх учинення; б) роз'яснено кримінально-правові поняття, термінологічні звороти та 
ознаки, що стосуються окремих видів суспільно небезпечної поведінки; в) передбачено спеціальні види звільнення від кримінальної відповідальності за окремі злочини; г) установлено винятки із загальних правил настання кримінальної відповідальності.

Статті Особливої частини КК Румунії складаються $з$ однієї або декількох частин, кожна з яких є окремою кримінально-правовою нормою, що містить самостійний склад злочину. Норми Особливої частини КК визначають, які саме суспільно небезпечні діяння $є$ злочинами та які покарання передбачено за їх учинення. Особлива частина описує конкретні види злочинів, основні та додаткові покарання за них. Починається вона зі статті 188 і закінчується статтею 446. Кожен злочин описується детально і має кваліфікуючі ознаки. Система Особливої частини КК Румунії складається з XIII розділів [10], a came:

I розділ - Злочини проти особи (статті 188-227);

II розділ - Злочини проти спадщини (статті 228-256);

II розділ - Правопорушення, пов'язані 3 державною владою та кордоном (статті 257-265);

IV розділ - Злочини проти правосуддя (статті 266-288);

$\mathrm{V}$ розділ - Корупція та службові правопорушення (статті 289-309);

VI розділ - Фальсифікація (статті 310-328);

VII розділ - Злочини проти громадської безпеки (статті 329-366);

VIII розділ - Правопорушення, що впливають на соціальні відносини (статті 367-384);

IX розділ - Злочини у виборчій сфері (статті 385-393);
Х розділ - Злочини проти національної безпеки (статті 394-412);

XI розділ - Правопорушення проти збройних сил (статті 413-437) XII розділ - Геноцид людства i військові злочини (статті 438-445); XIII розділ - Заключні положення (стаття 446).

Захист життя, свободи особи $є$ пріоритетним для КК Румунії. Саме через це перший розділ має назву «Злочини проти особи». Наприклад, стаття 189 КК Румунії передбачає відповідальність за кваліфіковане вбивство, тобто вчинене за будь-яких з наступних обставин: 1) з наміром; 2) за матеріальним інтересом; 3) 3 метою ухилення від покарання за попередній злочин або від відбування покарання взагалі; 4) полегшити або приховати вчинення іншого злочину; 5) особою, яка раніше вчинила вбивство або спробу вбивства; 6) двома або більше особами; 7) вагітної жінки; 8) з особливою жорстокістю.

Також у КК Румунії міститься стаття, що передбачає відповідальність за вбивство особи на її прохання (стаття 190). Убивство, учинене задля полегшення страждань особи, яка була невиліковно хворою або інвалідом, і при цьому постійно страждала через біль, карається позбавленням волі на строк від одного до п'яти років.

Наукові дослідження, проведені румунськими фахівцями, засвідчують, що з набранням чинності новим КК Румунії криміногенна обстановка в країні поступово стабілізується. Про це свідчать і статистичні дані, розміщені в World Prison Brief (Світові дані в'язниць). На даний момент у Румунії знижується і чисельність злочинців. Так, у 2015 р. кількість затриманих осіб, які скоїли 
кримінальні злочини та проступки, складала 2453 особи, а у 2018 р. 2098 осіб [11].

Висновки. Із наведеного можна зробити низку висновків.

По-перше, зміна КК Румунії була зумовлена застарілою нормативною базою, що або втратила чинність або зі зміною суспільного ладу вже не мала великого значення. У таких змінах спостерігаються політичні зрушення, що відбуваються в Румунії зараз. Також слід відзначити, що сучасна правова база Румунії $\epsilon$ досить розвиненою, і це $\epsilon$ важливо для створення держави, у якій права громадян займають основне місце.

По-друге, чинний КК Румунії містить значну кількість новел, які суттєво відрізняються від попереднього КК. Основними є захист прав і свобод громадянина. Також КК Румунії має широкий спектр положень, тому що не просто відстоює права потерпілих осіб, а й захищає права осіб, які вчинили певний злочин.

По-третє, основними ознаками, що пов'язують Загальну та Особливу частину КК Румунії, є такі:

1. Вони закріплені в одному й тому самому кримінальному законі.

2. Загальна і Особлива частини мають єдине завдання - боротьба зі злочинністю, у них відображена воля румунського законодавця.

3. Загальна і Особлива частини втілюють єдину кримінальну політику держави в боротьбі зі злочинністю.

4. Загальна й Особлива частини побудовані на однакових принципах.
5. Норми Загальної та Особливої частин застосовуються лише ваємопов'язано. Жодна норма Загальної частини не може бути застосована, якщо не конкретизувати їі зміст стосовно окремих видів злочинів, положень, що закріплені в Особливій частині. I навпаки, жодна норма Особливої частини не може бути застосована у відриві від положень, що містяться в нормах Загальної частини КК.

По-четверте, основними відмінностями між Загальною та Особливою частинами є:

1. Норми Загальної частини регламентують положення, що однакові для всіх чи більшості злочинів, а норми Особливої частини - тільки для злочинів окремих видів.

2. Норми Загальної та Особливої частин, зазвичай, мають різну структуру: норми Загальної частини складаються з гіпотези та диспозиції, норми Особливої частини - 3 диспозиції та санкції (за винятком нормдефініцій) та норм про умови звільнення від кримінальної відповідальності за окремі злочини.

Загалом, КК Румунії за своїм складом, змістом, основними положеннями, видами злочинів, видами покарання тощо схожий на КК України. Отже, можна стверджувати, що новий КК Румунї становить для України значний інтерес. Після грунтовного вивчення КК Румунії, іншої нормативної бази та практики їі застосування можна буде сформулювати пропозиції, які допомогли б удосконалити КК України. 


\section{Список використаних джерел}

1. Сухарев А. Я. Правовые системы стран мира: Энциклопедический справочник. Москва : Норма, 2003. 976 с.

2. Хавронюк М. І. Історія кримінального права європейських країн : монографія. Київ : Істина, 2006. 192 с.

3. Legal search engine maintained by Washburn University School of Law Library. URL: http://www.washlaw.edu/forint/europe/romania.html (дата звернення: 12.05.2019).

4. This English-language database is a portion of Pritchard Law Webs' Internet Law Library, which is the successor to the US House of Representatives Internet Law Library. URL: http://www.priweb.com/internetlawlib/79.htm (дата звернення: 22.05.2019).

5. New Civil Codes in Hungary and Romania edited by Attila MenyhLrd, Emd Veress. URL: http://julius.law.nyu.edu/search $\sim$ S0?/XRomania+\&SORT=D/ XRomania+\&SORT=D\&SUBKEY=Romania+/1\%2C2031\%2C2031\%2CB/ (дата звернення: 12.05.2019).

6. Romanian database of various legal codes. URL: http://www.dsclex.ro/coduri/ coduri.htm. (дата звернення: 12.05.2019).

7. George D. H. For the analysis of the existing changes in the General part of the new Criminal code. Bucharest : Universul Juridic Publishing House, 2011. 150 p.

8. Antoniu D. H. Noul Code penal. Bucharest : Beck Publishing House, 2005. 145 p.

9. Gherghevici I. Romanian database of central legal codes, assembled and maintained. URL: http://legal.dntis.ro/index.html (дата звернення: 12.05.2019).

10. Codul Penal al Romaniei. Publicat in Monitorul Oficial. Curinsul Legii nr. 286/2009 privind Codul penal. URL: http://www.avocatura.com/ll491-noul-codpenal.html. (дата звернення: 12.05.2019).

11. World Prison Brief. URL: http://www.prisonstudies.org/country/ Romania (дата звернення: 12.05.2019).

12. Medrea N. The court system in the USA, the UK and Romanian translation issues. URL: http://www.academia.edu/7636984/THE_COURT_SYSTEMS_IN_THE_USA_THE_UK_ AND_ROMANIA_TRANSLATION_ISSUES (дата звернення: 12.05.2019).

\section{References}

1. Sukharev, A. Ya. (2003). Pravovye sistemy stran mira: Enciklopedicheskij spravochnik. Moskva: Norma [in Russian].

2. Havronyuk, M. I. (2006). Istoriya kriminalnogo prava yevropejskih krayin: monografiya. Kiyiv: Istina [in Ukrainian].

3. Legal search engine maintained by Washburn University School of Law Library. URL: http://www.washlaw.edu/forint/europe/romania.html (accessed: 12.05.2019) [in English].

4. This English-language database is a portion of Pritchard Law Webs' Internet Law Library, which is the successor to the US House of Representatives Internet Law Library. URL: http://www.priweb.com/internetlawlib/79.htm (accessed: 22.05.2019) [in English].

5. New Civil Codes in Hungary and Romania edited by Attila MenyhLrd, Emd Veress. URL: http://julius.law.nyu.edu/search $\sim$ S0?/XRomania+\&SORT=D/XRomania+\& SORT=D\&SUBKEY=Romania $+/ 1 \% 2 C 2031 \% 2 C 2031 \% 2 C B / \quad$ (accessed: 12.05.2019) [in English].

6. Romanian database of various legal codes. URL: http://www.dsclex.ro/coduri/ coduri.htm. (accessed: 12.05.2019) [in English].

7. George, D. H. (2011). For the analysis of the existing changes in the General part of the new Criminal code. Bucharest: Universul Juridic Publishing House [in English]. 
8. Antoniu, D. H. (2005) Noul Code penal. Bucharest: Beck Publishing House [in Romanian].

9. Gherghevici, I. Romanian database of central legal codes, assembled and maintained. URL: http://legal.dntis.ro/index.html (accessed: 12.05.2019) [in English].

10. Codul Penal al Romaniei. Publicat in Monitorul Oficial. Curinsul Legii nr. 286/2009 privind Codul penal. URL: http://www.avocatura.com/l1491-noul-codpenal.html. (accessed: 12.05.2019) [in Romanian].

11. World Prison Brief. URL: http://www.prisonstudies.org/country/ Romania (data zvernennya: 12.05.2019) [in English].

12. Medrea, N. The court system in the USA, the UK and Romanian translation issues. URL: http://www.academia.edu/7636984/THE_COURT_SYSTEMS_IN_THE_USA_THE_UK_ AND_ROMANIA_TRANSLATION_ISSUES (accessed: 12.05.2019) [in English].

\section{S. Denisov, Doctor of Law, Professor} Service

A. Shyshova, Postgraduate Student of the Academy of the State Penitentiary

\section{Characteristics of the Romanian Criminal Code}

The article is dedicated to the study of the Romanian Criminal Code. Proper regulation of the institution of criminal responsibility and the existence of a coherent concept of its understanding is absolutely important for the criminal policy of the state. This article examines the main and additional types of punishments provided for crimes in this country, the principles under which the Criminal Code of Romania applies. The system of the Special Part of the Criminal Code of Romania was also outlined. A brief description of the Romanian legal system is given.

The focus is on current trends for improvement criminal law, factors that influence this process. Some changes to the Romanian Criminal Code are analyzed.

Formation of the rule of law requires adherence to the idea of «law above all else». The laws should express the objectively developing public relations, their tendencies for development and self-renewal, their self-organizing potential. And in the Criminal Code of Romania, the idea of a humane, just punishment «within» should be expressed as a codified legislative act.

In general, the Criminal Code of Romania, in its composition, content, main provisions, types of crimes, types of punishment, etc. is similar to the Criminal Code of Ukraine. Therefore, it can be argued that the new Criminal Code of Romania is of considerable interest to Ukraine. After a thorough study of the Criminal Code of Romania, other regulatory frameworks and practices, it will be possible to formulate proposals that would help improve the Criminal Code of Ukraine.

Keywords: Criminal code of Romania; General part of the Criminal code of Romania; System of the Special part of the Criminal code of Romania.

Надійшла до редакції 23.07.2019 